This article was downloaded by: [Universidad de Cuenca]

On: 12 June 2015, At: 06:59

Publisher: Routledge

Informa Ltd Registered in England and Wales Registered Number: 1072954 Registered

office: Mortimer House, 37-41 Mortimer Street, London W1T 3J H, UK

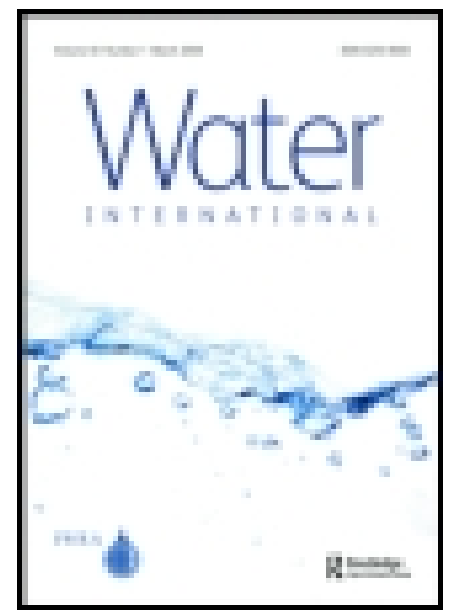

\title{
Water International
}

Publication details, including instructions for authors and subscription information:

http:// www.tandfonline.com/loi/ rwin20

\section{Forests and floods in Latin America: science, management, policy and the EPIC FORCE project}

James C. Bathurst ${ }^{a}$, J aime Amezaga ${ }^{b}$, Felipe Cisneros ${ }^{c}$, Marcelo Gaviño Novillo ${ }^{d}$, Andrés Iroumé ${ }^{e}$, Mario A. Lenzi ${ }^{f}$, J uan Mintegui Aguirre ${ }^{g}$, Miriam Miranda ${ }^{h} \&$ Adriana Urciuolo ${ }^{i}$

${ }^{a}$ School of Civil Engineering and Geosciences, Newcastle University, Newcastle upon Tyne, UK

${ }^{b}$ Sir J oseph Swan Institute for Energy Research, Newcastle University, Newcastle upon Tyne, UK

c Universidad de Cuenca, Cuenca, Programa para el Manejo de Agua y Suelo (PROMAS), Department of Water and Soil Resources Engineering , Cuenca, Ecuador

d Facultad de Ingeniería, Departamento de Hidráulica, Universidad Nacional de La Plata, La Plata, Argentina

e Universidad Austral de Chile, Faculty of Forest Sciences, Institute of Forest Management, Valdivia, Chile

${ }^{f}$ Water Resources Division, Department of Land and Agroforest Environments, Università degli Studi di Padova, Legnaro, Italy

${ }^{g}$ Escuela Técnica Superior de Ingenieros de Montes,

Departamento de Ingeniería Forestal, Universidad Politécnica de Madrid, Madrid, Spain

${ }^{\mathrm{h}}$ Centro Internacional en Política Económica para el Desarrollo Sostenible (CINPE), Fundación Universidad Nacional de Costa Rica, HEREDIA Centro, Frente al hito de la bandera de la Universidad Nacional, San J osé, Costa Rica

i Secretaría de Desarrollo Sustentable y Ambiente de Tierra del Fuego, Ushuaia, Argentina

Published online: 08 Apr 2010.

To cite this article: J ames C. Bathurst , J aime Amezaga , Felipe Cisneros, Marcelo Gaviño Novillo , Andrés Iroumé , Mario A. Lenzi , J uan Mintegui Aguirre, Miriam Miranda \& Adriana Urciuolo (2010) Forests and floods in Latin America: science, management, policy and the EPIC FORCE project, Water International, 35:2, 114-131 


\section{PLEASE SCROLL DOWN FOR ARTICLE}

Taylor \& Francis makes every effort to ensure the accuracy of all the information (the "Content") contained in the publications on our platform. However, Taylor \& Francis, our agents, and our licensors make no representations or warranties whatsoever as to the accuracy, completeness, or suitability for any purpose of the Content. Any opinions and views expressed in this publication are the opinions and views of the authors, and are not the views of or endorsed by Taylor \& Francis. The accuracy of the Content should not be relied upon and should be independently verified with primary sources of information. Taylor and Francis shall not be liable for any losses, actions, claims, proceedings, demands, costs, expenses, damages, and other liabilities whatsoever or howsoever caused arising directly or indirectly in connection with, in relation to or arising out of the use of the Content.

This article may be used for research, teaching, and private study purposes. Any substantial or systematic reproduction, redistribution, reselling, loan, sub-licensing, systematic supply, or distribution in any form to anyone is expressly forbidden. Terms \& Conditions of access and use can be found at http://www.tandfonline.com/page/termsand-conditions 


\title{
Forests and floods in Latin America: science, management, policy and the EPIC FORCE project
}

\section{In memoriam: Ian Rainy Calder (1945-2009)}

James C. Bathurst ${ }^{\mathrm{a} *}$, Jaime Amezaga ${ }^{\mathrm{b}}$, Felipe Cisneros ${ }^{\mathrm{c}}$, Marcelo Gaviño Novillo ${ }^{\mathrm{d}}$, Andrés Iroumée, Mario A. Lenzi ${ }^{\mathrm{f}}$, Juan Mintegui Aguirre ${ }^{\mathrm{g}}$, Miriam Miranda ${ }^{\mathrm{h}}$ and Adriana Urciuolo ${ }^{\mathrm{i}}$

\begin{abstract}
${ }^{a}$ School of Civil Engineering and Geosciences, Newcastle University, Newcastle upon Tyne, UK; ${ }^{b}$ Sir Joseph Swan Institute for Energy Research, Newcastle University, Newcastle upon Tyne, UK;

${ }^{c}$ Universidad de Cuenca, Cuenca, Programa para el Manejo de Agua y Suelo (PROMAS), Department of Water and Soil Resources Engineering, Cuenca, Ecuador; ${ }^{d}$ Facultad de Ingenieria, Departamento de Hidráulica, Universidad Nacional de La Plata, La Plata, Argentina;

${ }^{e}$ Universidad Austral de Chile, Faculty of Forest Sciences, Institute of Forest Management, Valdivia, Chile; ${ }^{f}$ Water Resources Division, Department of Land and Agroforest Environments, Università degli Studi di Padova, Legnaro, Italy; ${ }^{g}$ Escuela Técnica Superior de Ingenieros de Montes, Departamento de Ingeniería Forestal, Universidad Politécnica de Madrid, Madrid, Spain; ${ }^{h}$ Centro Internacional en Politica Económica para el Desarrollo Sostenible (CINPE), Fundación Universidad Nacional de Costa Rica, HEREDIA Centro, Frente al hito de la bandera de la Universidad Nacional, San José, Costa Rica; ${ }^{i}$ Secretaría de Desarrollo Sustentable y Ambiente de Tierra del Fuego, Ushuaia, Argentina
\end{abstract}

(Received 17 February 2009; final version received 16 January 2010)

The EPIC FORCE project aimed to develop science-based policy recommendations for integrated forest and water resources management, relevant to extreme events for Costa Rica, Ecuador, Chile and Argentina. Data analysis and model application support the hypothesis that, as the size of the flood peak increases, the effect of forest cover becomes less important. Guidelines for integrated water and forest resources management are developed which recognize this effect but emphasize the role that forests play in reducing the flood levels of more moderate events. The research findings are transferred to policy-making for the four focus countries via a set of policy briefs, taking into account the institutional frameworks, achievable policy objectives and key stakeholders.

Keywords: floods; forests, Latin America; policy; river catchments

\section{Introduction}

Deforestation and logging are regularly blamed by the public and the media for exacerbating the disastrous effects of floods generated by extreme rainfall, such as hurricanes. Consequently large sums of money are invested by governments and development agencies in foresting headwater areas of river catchments and land use controls are imposed on the (typically poor) populations living in these areas (CIFOR and FAO 2005, Calder 2005,

*Corresponding author. Email: j.c.bathurst@ncl.ac.uk 
Calder and Aylward 2006). However, the impact of forest management on catchment response for extreme rainfall events is an area in which there is considerable scientific uncertainty as well as poorly conceived policy (e.g. Beschta et al. 2000, Brath et al. 2006, López-Moreno et al. 2006, Bradshaw et al. 2007). The EPIC FORCE project (Evidencebased Policy for Integrated Control of Forested River Catchments in Extreme Rainfall and Snowmelt), funded by the European Commission and focused on Latin America, therefore aimed to develop policy recommendations for the integrated management of forest and water resources, based on improvements in understanding the effects of land use on catchment response for extreme rainfall and snowmelt events and the creation of a framework within which to develop management strategies. Following DeWalle (2003), the results were intended to serve as a guide to the practice of forest management at a national scale and to help reshape the attitudes of the general public regarding forests and floods.

This paper first establishes the contribution of the project in integrating the objective scientific study of the hydrological impacts of forests with the empirically derived best practices for forest and water management as a basis for policy-making. It then describes the project methodology and focus areas, proposes a definition for an extreme event and summarizes the results concerning forest impacts, the development of improved strategies for integrated water and forest resource management and the development of evidencebased policies.

\section{Context for integrated water and forest resource management}

A number of public misperceptions have accumulated over the hydrological role of forests (Calder 2005). However, they are poorly, or at best partially, supported by the available hydrological evidence. Thus, recent research suggests that, while forests may be helpful in moderating floods for small events, this effect is increasingly reduced as rainfall amounts increase (e.g. Beschta et al. 2000, López-Moreno et al. 2006). Scientific hydrology therefore has a clear role to play in critically examining and either disproving these misperceptions or establishing their exact veracity. The resulting improved understanding then contributes to the development of evidence-based policies for the integrated management of water and forest resources.

Nevertheless, the scientific study of water and forest interactions is still limited in its ability to consider the full complexity of conditions in which water and forest management is practised in reality. Even among paired catchment studies, which represent relatively ideal conditions such as uniform vegetation and small areas, there is considerable variation in the measured response to changes in forest cover. The response to the change of cover (i.e. forest biomass) has also to be distinguished from the response to the practices used in implementing the change, such as logging technique and road building (e.g. La Marche and Lettenmair 2001, DeWalle 2003). The response may be expected to vary still further with heterogeneity of land use and management techniques, attenuation at large scales, altitudinal dependencies, forest age, soil properties and other characteristics. Nevertheless, there has been a continuing need to develop strategies for catchment management and, as a result, a strong basis of empirically derived knowledge has been created. This is especially rooted in over a century of experience of successes and failures in catchment restoration in Europe (e.g. Andréassian 2004, Mintegui and Robredo 2008), aimed at countering the adverse impacts of both natural (extreme) events and human activities (e.g. poorly conceived land use changes) on catchment response. The approach is known as water and forest management and restoration, recognizing that catchment 
responses and impacts depend on both stream channel and hillslope characteristics and conditions.

Policy-makers require a basis for policy formulation which is both reliable and sufficiently flexible to incorporate the variability not only of the present but of an increasingly uncertain future. Neither of the above two approaches provides a sufficient basis on its own. Research-based forest hydrology introduces a potential for prediction but may not represent the full complexity of actual conditions and is therefore a restricted guide. Historical experience provides a basis for best practice but does not necessarily take scientific understanding into account and, because it is empirical, may not provide a sound basis for management in a changing future (for example, with climate change) or a different environment (e.g. outside Europe). One way forward is therefore to combine the understanding of both. However, this combined approach needs to be tested in an environment different from that providing the historical experience, so as to investigate its transferability and the possibilities for its systematic application. The contribution of the EPIC FORCE project is then the integration of an improved understanding of the effects of land use on catchment response for extreme rainfall and snowmelt with historically derived management principles; this provides a framework within which to develop catchment management strategies and so to propose evidence-based policy recommendations for the integrated management of water and forest resources. The applicability of this approach is tested in the Latin American environment, which differs from the European environment in such terms as biophysical characteristics, data availability, institutional structures and policy needs.

\section{The EPIC FORCE project}

To achieve its aims, the project had three major objectives:

(1) To examine the hypothesis that, as the size of the flood peak increases, the effect of forest cover becomes less important; this was addressed through a combination of model application and analysis of data from focus areas in the Latin American countries;

(2) To develop improved strategies for integrated forest and water management relevant to extreme events, including the management of large woody debris, such as logs, within river channels; this was addressed by combining the results of the land use impact study with the understanding of current management practice and of best international practice, in a context of targeted field surveys;

(3) To develop evidence-based policy recommendations for national and international agencies, by proposing improvements to the basis of existing national policies in the focus countries in the light of the impact and management studies.

The focus areas were in Costa Rica, Ecuador, Chile and Argentina. They represent both tropical and temperate rainforests and are subjected to extremes of rainfall from hurricanes, El Niño events and mid-latitude depressions and, in the case of Argentina, to snowmelt. In addition these countries suffer major problems of flooding and erosion, are characterized by rapid forest conversion or extensive forestry activities and suffer from a lack of integrated and consistent water and forest management policies.

Full details of the results achieved for each of the above objectives are given on the project website (http://www.ceg.ncl.ac.uk/epicforce) and are to be published elsewhere: this paper can provide only an overview. 


\section{Extreme events}

In order to place extreme rainfall in context, a conceptual model was developed for defining the different scales of flood events and assessing the associated requirement for management strategies for prevention and mitigation of damage.

The traditional definition of an extreme event, as one that occurs infrequently, i.e. with a long recurrence interval, is not entirely suitable for hurricanes, which are certainly extreme events but which may affect a site relatively frequently. Relatively low magnitude events, with short recurrence intervals, can also cause significant damage, especially in areas of poor land management. An extreme event is therefore defined here as one that causes damage over a certain acceptable level. The occurrence of a damaging event depends on both the generating process (i.e. the precipitation characteristics) and the catchment response. The greater the rainfall intensity and spatial occurrence and the rarer the rainfall event, the greater is likely to be the impact in terms of, for example, floods and landslides. The catchment response depends on its various characteristics, some of which are relatively little affected by human activities (e.g. geology and topography), others of which can be strongly affected (e.g. vegetation cover, land use and river channel morphology). While human activities often worsen the flood impact, they can also be directed to lessening the damage, for example through tree cover to reduce soil erosion. Plotting a precipitation index (involving intensity, spatial distribution and frequency distribution) against catchment characteristics (including human interventions as well as natural conditions) enables different levels of events to be defined (Figure 1). Suggested definitions are given in Table 1. Categorization of an event is useful for the development of different policies and management strategies to avoid or minimize the associated damage. Figure 1 also shows how human interventions (represented by a change in catchment characteristics) can affect the potential for different levels of event. The dashed curves represent a catchment with poor land management while the solid curves show the result of well-planned management.

\section{Impact of land use on peak discharge for extreme events}

Data analysis was carried out to quantify directly the impact of forest cover on catchment response to extreme rainfall or snowmelt for each of the focus areas. Model applications

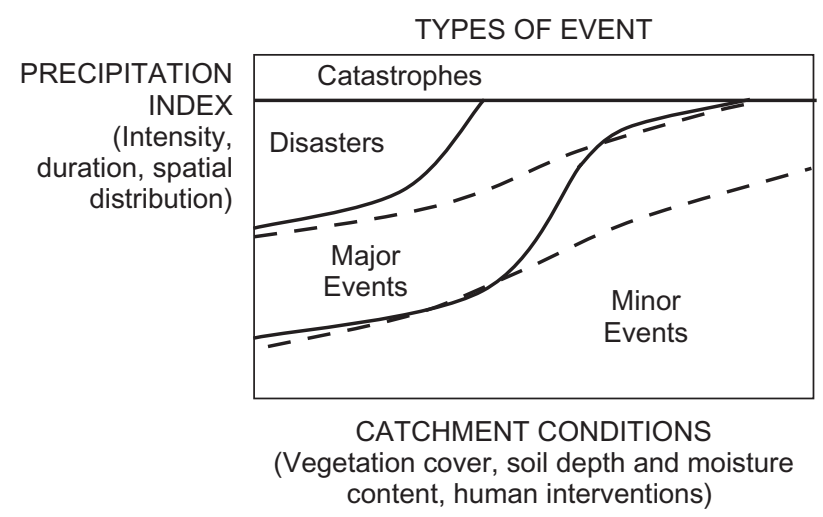

Figure 1. Plot of precipitation index against catchment response for defining different scales of event. 
Table 1. Proposed definitions of event scale and associated policy and management strategies.

\begin{tabular}{|c|c|c|}
\hline Event category & Definition & Policy/management strategies \\
\hline Catastrophic & $\begin{array}{l}\text { Precipitation index implies impacts } \\
\text { independent of catchment features. Large } \\
\text { changes in river morphology, regional } \\
\text { geomorphological impact (e.g. extensive } \\
\text { landsliding), extensive damage to main } \\
\text { infrastructure and urban areas in the } \\
\text { floodplain }\end{array}$ & $\begin{array}{l}\text { Emergency response, warning } \\
\text { systems, vulnerability } \\
\text { assessment, policies on } \\
\text { infrastructure development and } \\
\text { land use in danger areas (e.g. } \\
\text { from EPIC FORCE project) }\end{array}$ \\
\hline Disastrous & $\begin{array}{l}\text { Precipitation index implies impacts where } \\
\text { vegetation cover is below a critical level, } \\
\text { depending also on catchment physical } \\
\text { features. Water and sediment movements } \\
\text { outside the floodplain, erosion and } \\
\text { sedimentation outside the river channel, } \\
\text { damage to bridges and roads outside the } \\
\text { floodplain, local changes to } \\
\text { geomorphology (landslides) }\end{array}$ & $\begin{array}{l}\text { Land use policies, improvement of } \\
\text { adaptation and resilience } \\
\text { measures, vulnerability } \\
\text { assessment, management } \\
\text { strategies for critical catchment } \\
\text { areas (e.g. from EPIC FORCE } \\
\text { project) }\end{array}$ \\
\hline Major & $\begin{array}{l}\text { Moderate precipitation index implies } \\
\text { impacts depending on vegetation cover } \\
\text { and predisposition of catchment to slope } \\
\text { failures. Frequent events (recurrence } \\
\text { interval two years), water and sediment } \\
\text { movements within the flood plain, erosion } \\
\text { and sedimentation within the river } \\
\text { channel, damage to infrastructure within } \\
\text { the floodplain, movement of large woody } \\
\text { debris in the channel }\end{array}$ & $\begin{array}{l}\text { Land use regulation, integrated } \\
\text { catchment management (to } \\
\text { maintain effective vegetation } \\
\text { cover), channel engineering, } \\
\text { specific management strategies } \\
\text { (e.g. from EPIC FORCE } \\
\text { project) }\end{array}$ \\
\hline Minor & $\begin{array}{l}\text { Precipitation index low enough that, } \\
\text { depending on vegetation cover and } \\
\text { catchment physical condition, there may } \\
\text { be no significant hillslope erosion. } \\
\text { Frequent events, water and sediment } \\
\text { movements within the river channel } \\
\text { (bankfull), damage to some infrastructure } \\
\text { within the river channel }\end{array}$ & $\begin{array}{l}\text { Integrated catchment management } \\
\text { (to maintain effective vegetation } \\
\text { cover) }\end{array}$ \\
\hline
\end{tabular}

were also performed to extrapolate the analyses to a wider range of conditions and to provide a systematic analysis of the impact of land use on flood peak discharge using a standard approach.

The hypothesis that was examined is illustrated in Figure 2, which shows the relationship between peak discharge and flood frequency (quantified by return period) for catchments that are identical except for the level of forest cover. In both cases, the less frequent the flood (i.e. with a greater return period), the greater is the peak discharge. For moderate floods, which are relatively frequent, the forested catchment is able to absorb more rainfall into the soil and therefore has lower peak discharges than the non-forested catchment. This is because the greater interception of rainfall by the forest, combined with a higher transpiration by the trees, allows the build-up of greater soil moisture deficits compared with the non-forested case. However, the impact of this effect is expected to decrease as rainfall amounts increase. The diagram thus proposes a convergence of peak discharge response for the more extreme floods. 


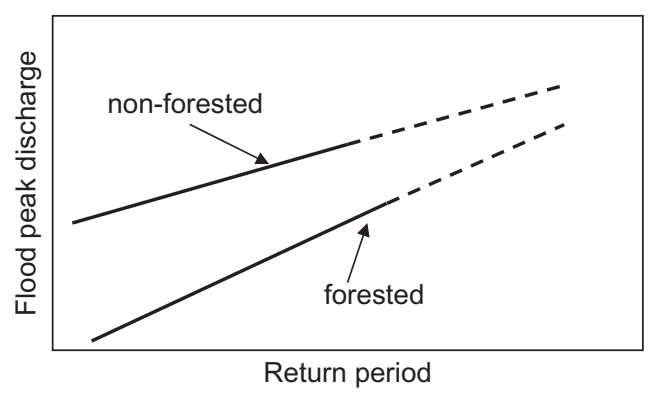

Figure 2. The hypothesis that, as the size of the flood peak increases (i.e. the flood has a greater return period), the effect of land use on the flood peak discharge decreases.

\section{Focus sites}

Figure 3 illustrates the wide distribution of the focus catchments; Table 2 summarizes their general environments and management needs. Although the catchments are mostly small, in Costa Rica and Chile it was possible to extend the analysis to larger areas of hundreds to thousands of square kilometres. It is important to consider the larger scale because: (1) it is possible that responses observed at small scales may be attenuated or

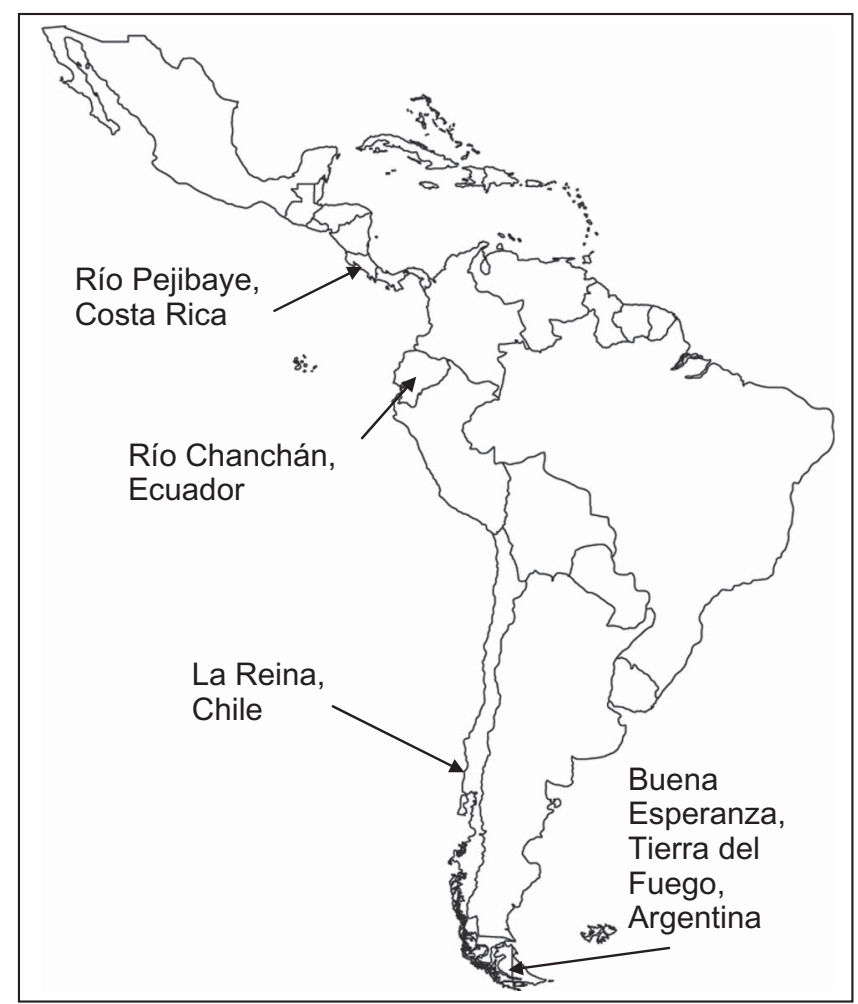

Figure 3. Location map for the focus sites. 


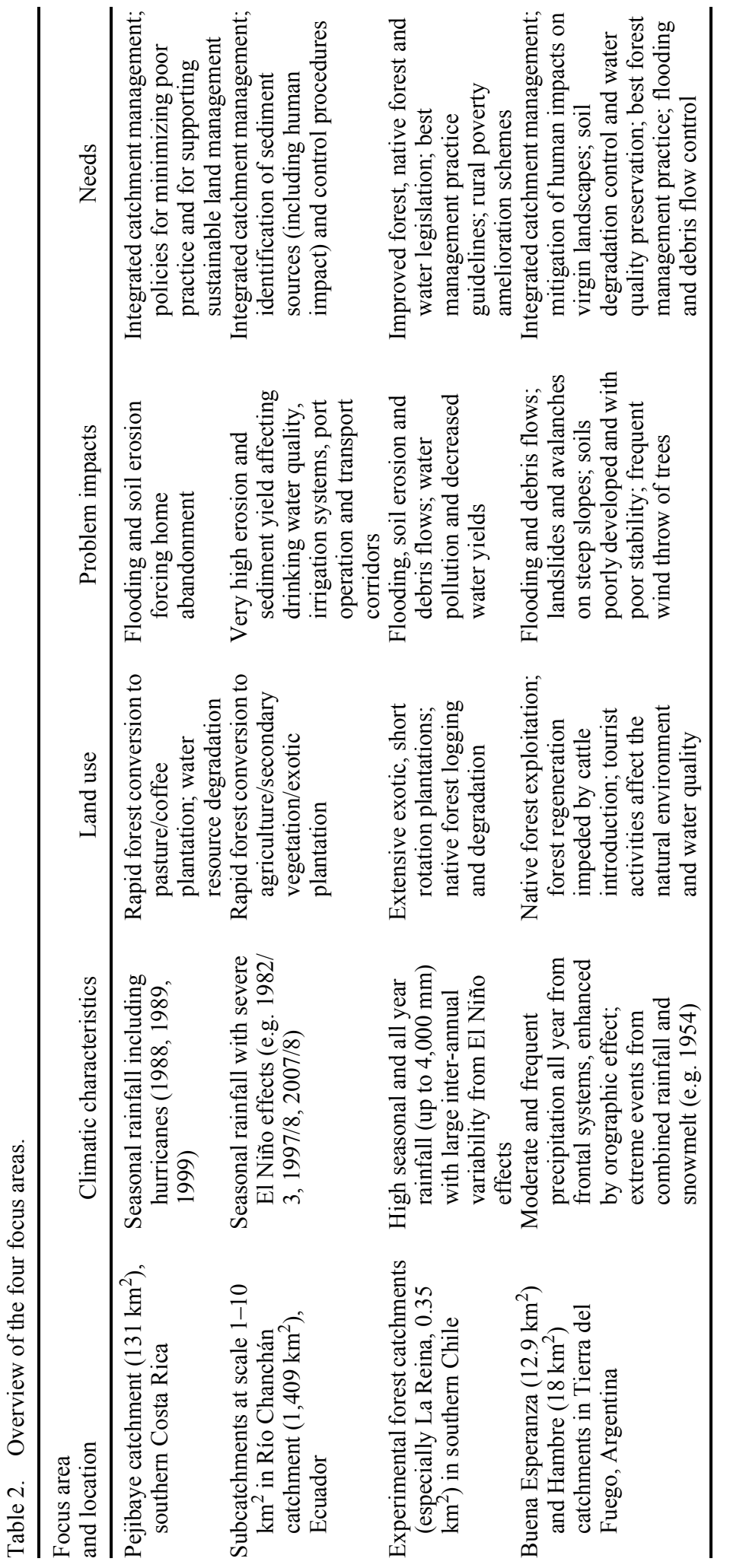


diluted at larger scales; and (2) larger scales are more relevant to planning considerations and provide a more appropriate basis for making policy recommendations to national agencies.

\section{Methodology - data analysis}

Because of the different availabilities of instrumented catchments, different approaches to the data analysis were followed in the focus areas.

\section{Costa Rica}

Flood regimes were analyzed as a function of the history of land use, both for the Pejibaye catchment (which has been largely deforested) and the larger $\left(1,475 \mathrm{~km}^{2}\right)$ Matina catchment (in which the forest cover has remained constant at about $81 \%$ since the 1970 s).

\section{Ecuador}

For a range of rainfall events, peak stream discharges were compared for neighbouring paired catchments, selected for their contrasting vegetation covers, for the period 20052007 , e.g. the $10 \mathrm{~km}^{2}$ Panamá catchment (mainly grassland cover) and the $2.3 \mathrm{~km}^{2}$ Lise catchment (largely forested) lying within the larger Río Chanchán catchment (Coello et al. 2007).

\section{Chile}

Peak flow characteristics were compared for La Reina catchment for a full forest cover (1997-99) and following clearfelling of the Pinus radiata plantation that covered $79.4 \%$ of the catchment (2000-2002). The analysis was extended to three larger catchments (Caramávida [94 km²], Mulchén [434 km²], and Duqueco [1,545 km²]) which have undergone significant plantation affecting at least $30 \%$ of the catchment area.

\section{Argentina}

An analysis of the effects of forest cover on seasonal snow accumulation and melt was carried out, based on experience reported in the scientific literature and adapted to the particular conditions of the Buena Esperanza focus catchment.

\section{Methodology - model application}

Simulations were carried out using the SHETRAN modelling system (Ewen et al. 2000). This is a physically based, spatially distributed modelling system for flow and sediment transport, relevant at the catchment scale. It includes components for modelling vegetation interception and transpiration, snowmelt, overland flow, variably saturated subsurface flow, river/aquifer interaction and sediment yield.

SHETRAN was calibrated against the limited discharge data for the Pejibaye, Panamá, La Reina and Buena Esperanza catchments. Then a 1,000-year synthetic hourly precipitation time series, representative of current conditions, was generated for each catchment from available precipitation data, to provide an appropriate statistical basis for defining the flood response for events with return periods of up to 100 years or so. SHETRAN was 
then applied to contrasting land use scenarios (generally with and without a forest cover) using the generated precipitation time series. The maximum daily discharges for the contrasting scenarios were compared for each day of the 1,000 -year simulations so as to investigate the degree to which the contrasting responses converge as the size of the flood peak increases.

\section{Results}

\section{Costa Rica}

Nationally there has been an increase in the number of damaging floods in the last 30 years, coinciding with the conversion of forest to farming and urban areas. (These floods are defined as those causing damage and are not necessarily the total number of floods.) However, the forested Matina catchment has experienced a similar increase in damaging floods. The most likely reason for the increase is therefore the greater occupation of the flood plain; i.e. the increase is in the impact rather than the number of floods. This suggests that land use change is not responsible for the increase and that forest cover does not eliminate the threat of floods: floods are part of the normal hydrological behaviour. For the Pejibaye catchment, the reduction in the percentage of the catchment covered by native forest from about $20 \%$ to $3.5 \%$ during 1970 to 2000 is found to be too small to have had a significant impact on mean annual discharge or flood return periods. Runoff is instead dominated by rainfall totals, with significant inter-annual variations.

\section{Ecuador}

Data analysis for two pairs of catchments and the simulation results support each other. A forested catchment has lower flood peak discharges than a grassland catchment but the difference between the two decreases as discharges increases; the convergence may be absolute or relative (i.e. the difference between the two is constant but decreases as a percentage of the discharge as discharge increases); see, for example, Figure 4.

\section{Chile}

Comparison of peak flows for La Reina catchment between the pre- and post-harvesting conditions shows that the percentage difference for "large" rainfall events (for rainfall volumes greater than $50 \mathrm{~mm}$ ) is less than that for "medium" events (rainfall volumes of $10-50 \mathrm{~mm}$ ) and "small" events (rainfall volumes of 5-10 mm) (Iroumé et al. 2006). The simulations show relative convergence of the peak discharges as discharge increases but the pattern is affected by season, type of event, soil depth and antecedent soil moisture condition. For each of the large catchments, comparison of peak discharges for paired events (i.e. of similar rainfall) from the pre-plantation and post-plantation periods shows convergence for large events (Figure 5). Sediment transport simulations (carried out for the Chile site only) showed a clear benefit from forest cover in protecting the soil from erosion for all rainfall conditions and thus in reducing the sediment transport in the river system.

\section{Argentina}

Scientific considerations suggest that: tree cover has a significant influence on the accumulation, redistribution and melting of snow, acting to reduce peak flows in rain-on-snow 

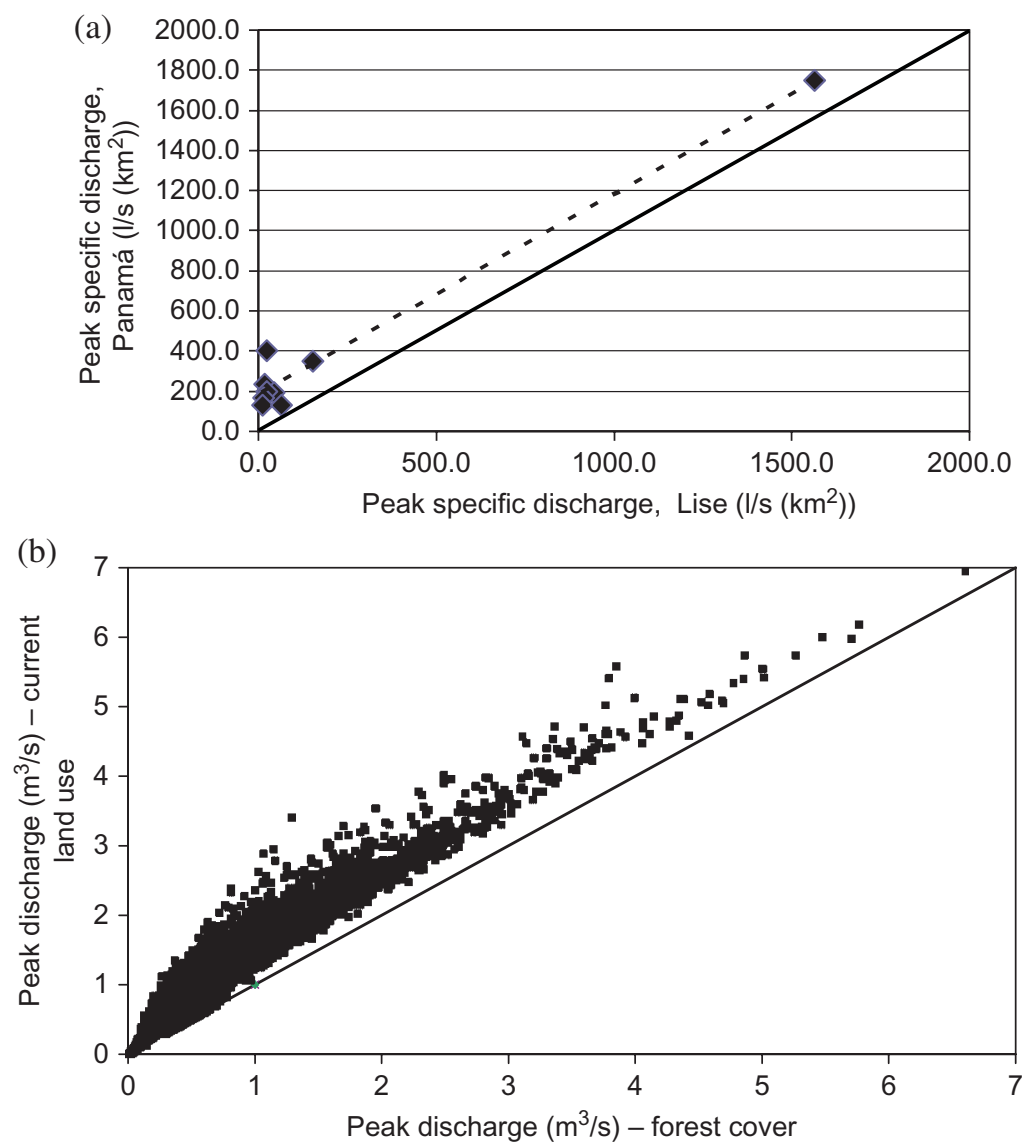

Figure 4. (a) Comparison of observed peak specific discharges for the Panamá and Lise catchments (Ecuador) for the same storm events. (b) Comparison of maximum daily discharges $\left(\mathrm{m}^{3} / \mathrm{s}\right)$ for the current vegetation and a hypothetical forest cover from the 1,000-year SHETRAN simulations of the Panamá catchment. Solid lines are lines of equality.

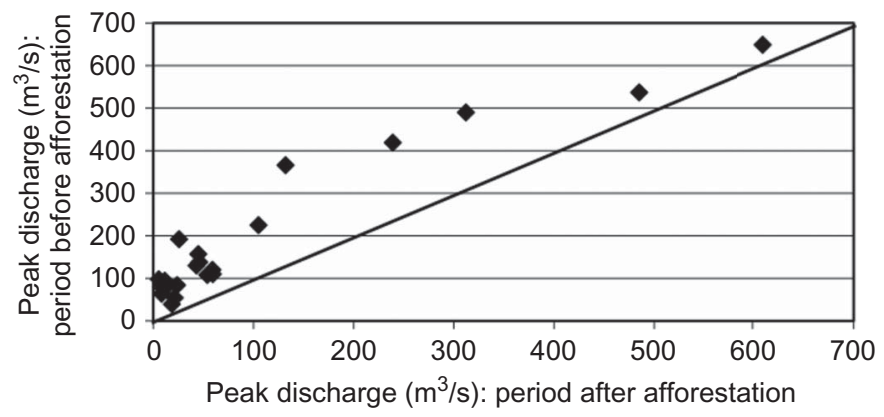

Figure 5. Comparison of paired peak discharges from before and after forest plantation in Duqueco catchment $\left(1,545 \mathrm{~km}^{2}\right)$, Chile. Line is line of equality. 
events; forest clearings promote greater snow accumulations and more active melting; and forest cover acts as a barrier to the redistribution of snow by wind from higher elevations to the lower elevations where higher temperatures support more rapid thawing. The simulations of the Buena Esperanza catchment show that, in general, removal of the trees which cover about $40 \%$ of the catchment increases the peak river discharge but, for certain conditions of snowmelt, there can be a reduction. These results indicate the complicating effect of snowmelt and the difficulty in distinguishing trends concerning land use effect on peak discharges for extreme events incorporating snowmelt.

\section{Strategies for water and forest resources management relevant to extreme events}

A framework of guidelines was created within which strategies for integrated water and forest resources management could be developed for a catchment. The framework was required to combine the best management practice at the international level (incorporating successful historical experience with water and forest management and restoration) with a sound scientific basis (including the above results concerning extreme events), while remaining sufficiently flexible to incorporate the individual characteristics of the Latin American catchments.

A fundamental aspect of the framework was recognition of the needs of the catchment's inhabitants. The framework therefore took as its starting point two principal objectives:

(1) The management of the catchment to protect its inhabitants against the impacts of rainfall and snowmelt events (both moderate and extreme) such as floods, soil erosion, debris flows and sediment depositions;

(2) The optimal management of the water and soil resources in support of a sustainable way of life for the inhabitants of the catchment.

Achieving these objectives requires an understanding of the characteristics of the catchment and a means of predicting its response to the full range of rainfall events.

The major components of the framework are:

(1) A matrix of scenarios for water and forest resources management in a catchment. The catchment is divided into an upper, headwater, part and a lower part, such that developments in the former could have an impact on conditions in the latter. Each of these parts is further divided according to altitude (higher and lower) and slope (greater or lower than 20\%). Eight scenarios are thus defined on the basis of the physical and flood characteristics; these provide a guide to selection of the appropriate flood control and other mitigation measures, including the potential for using forest cover.

(2) A matrix of processes triggered by or associated with rainfall events (moderate and extreme), snowmelt events and periods between events, including: the hydrological phenomena, the hydrological impacts, the science basis for event and process analysis, the data required for impact analysis, mitigation techniques, and planning and management recommendations relevant to extreme events.

(3) A matrix of the criteria relevant to cost/benefit analysis for the proposed management strategy. The criteria include the mitigating effects of the strategy, methods for quantifying those effects (e.g. mathematical models), and economic criteria for evaluating the benefits of the strategy. A graphical scheme is also pro- 
posed for determining the cost (or damage) of an event on the basis of the conceptual model outlined in Figure 1. This could be applied using an understanding of the catchment characteristics and response mechanisms together with model simulations of the response for required event magnitudes. The conceptual model provides a means of developing appropriate management strategies for the different levels of event (minor, major, disastrous, catastrophic).

The framework of guidelines was used, in conjunction with site visits, to develop management strategies for each of the project focus areas. Full details are given in Mintegui and Robredo (2008).

\section{Costa Rica}

The Pejibaye catchment has been largely deforested and is characterized by cultivation and pasture. There is a need to provide flood protection and maintain the long-term sustainability of agriculture. Soils are vulnerable to erosion, especially by small shallow landslides, so there is a need to maintain vegetation cover and apply soil conservation measures. Secondary forest can quickly establish itself if so allowed, with good hydrological and soil protection benefits. It should therefore be allowed to develop in the more vulnerable areas of steep slopes and river banks.

\section{Ecuador}

The Chanchán catchment has been largely deforested and agriculture has spread to all areas, including steep slopes and the headwater páramo zone characterized by andosols which provide valuable soil water storage (Buytaert et al. 2005, Harden 2006, Borja et al. 2008). Once these soils are ploughed their hydrological function is lost irreversibly and they are easily eroded (Cisneros et al. 2007). There is a need to provide flood protection and soil conservation (especially of the andosols) while maintaining the long-term sustainability of agriculture. Where the andosols retain a well-conserved native vegetation cover (pajonal, a type of grassland), the recommendation is maintenance of that cover. Where the andosols have been ploughed and the soil profile has been degraded through water erosion processes, the recommendation is for reforestation. In addition, reforestation could be targeted on steeper slopes showing signs of erosion or shallow landsliding (e.g. Bathurst et al. 2010).

\section{Chile}

Good practices are required to support forest plantation management which is sustainable from the environmental and socio-economic points of view, with the aim of enabling forestry companies to achieve environmental certification for their operations. A major objective is to minimize sediment production and so maintain stream water quality. The required practices are well known and include the use of buffer strips to protect stream environments, design and use of forest roads to minimize drainage and sediment fluxes into streams, and minimization of soil disturbance by machinery and other forestry activities. 


\section{Argentina}

The Buena Esperanza catchment is used for water supply for Ushuaia and recreation. Important management objectives are the maintenance of the forest in its lower zone as protection for Ushuaia against rain and snowmelt floods and sediment depositions, sustainable use of the water resources and maintenance of the forest ecosystem for tourism and national heritage reasons. The benefit of the forest can be quantified by calculating the cost of the infrastructure which would otherwise be needed to provide the same level of protection for the urban area. It is recognized that the forest may not provide complete protection against a flood derived from an extreme event but it nevertheless protects very efficiently against a range of moderate to high floods, minimizing maintenance costs for roads, for example.

\section{Impact and management of large woody debris (LWD)}

Flood damage can be exacerbated by the battering effect of logs carried by the flow or by the sudden release of water (and sediment) when a log jam fails. The project therefore examined the role of large woody debris in river channels and the means that are available for managing its impact.

Measurements of woody debris characteristics in two Chilean headwater streams in the Andes foothills and in the Buena Esperanza stream in Argentina (Andreoli et al. 2007, Comiti et al. 2008a, Mao et al. 2008a) showed that old-growth forest in Chile in particular could yield high in-channel storage of wood: over $500 \mathrm{~m}^{3}$ per kilometre length of channel. It was found that the log jams formed by large woody debris in the stream channel can account for $25 \%$ of the total elevation drop along the channel and can store over $1,000 \mathrm{~m}^{3}$ of sediment per kilometre length of channel, which is comparable with annual yields. To these beneficial effects may be added the enhanced diversity of ecological habitat. It is therefore recommended that the removal of woody debris and riparian trees should be carried out only locally, for example where the failure of a log jam could have dangerous consequences.

Best practice guidelines for managing large woody debris were produced, with particular relevance to the protection of downstream urban areas (summarized by Mao et al. $2008 \mathrm{~b}$ ). The guidelines provide details on the design and construction of control structures such as check dams, rope nets, and cable filters, as well as riparian woodland management. However, control structures are expensive and decisions on their installation should involve cost-benefit analysis. A separate and detailed guide was provided for the design and use of check dams constructed from natural materials such as logs and boulders, with particular relevance to restoration of degraded rivers.

As much of the available literature concerns relatively small streams, the project research was specifically extended to larger rivers, where the impacts of large woody debris on settlements and infrastructure can also be serious (e.g. bridge blockage). A means of detecting and quantifying woody debris volumes in large gravel-bed rivers using high-resolution aerial photographs was successfully tested (Comiti et al. 2008b.).

\section{Development of evidence-based policy briefs and recommendations for water and forest resource management}

EPIC FORCE was designed as a policy-oriented project, paying particular attention to the involvement of local stakeholders and the joint development of recommendations based on local conditions and interests. The variety of local conditions and interests meant that the modes of interaction were different in each focus country. A common key feature, though, was the establishment of national working groups to provide the views of key 
stakeholders (such as national water and forest agencies) and the necessary legitimacy and policy links. The evidence basis was supplied by the forest impact research, the evaluation of forest and water resources management options and the analysis of existing national policies. The final outcome of the project was a set of policy briefs for the Latin American countries and for international agencies, integrating the impact, management and policy research. These briefs may be viewed at http://www.ceg.ncl.ac.uk/epicforce/assets/ D24.pdf. They are also being published by UNESCO's Regional Science Office for Latin America and the Caribbean (in Montevideo, Uruguay) as part of its International Hydrological Programme, in partnership with the Programme of Ecohydrology at the Universidad Nacional de La Plata, Argentina.

The main steps in the policy research were as follows, for each focus country: review of the institutional framework for relevant policy-making; presentation of the strategies that could be followed to maximize policy-impact in the three-year lifetime of the project; overview of the importance of extreme events; review of the institutional framework for the management of extreme events and forest and water resources; identification of the lessons emerging from the impact, management and policy research and from the stakeholder interaction; and production of consolidated policy recommendations. A set of nine policy briefs provide a summary of the general principles and findings of the project on extreme events, use of modelling and field data to support policy-making, the interaction between forests and water, the role of forests in extreme events, catchment restoration, and management of large woody debris. Sets of policy briefs were also written on topics specifically relevant to each focus country. The policy developments for each country are as follows.

\section{Costa Rica}

A strategy for policy impact was devised with a bottom-up approach working at the local level (Pejibaye focus catchment), national level (national working group) and CentroAmerican region level (Centro-American Support Group), following a multi-stakeholder approach (Warner 2005). An important element was the development of a methodology for creating participatory policies for catchment management. The overall theme was catchment protection for extreme events; in spite of the frequent emergencies due to hurricanes, the country does not have a long-term policy for land management to mitigate the impact of extreme events. Five targeted policy briefs were produced for the main national policy development and implementation agents in Costa Rica on managing the impact of land use on river discharge for extreme hydrometeorological events, managing the Pejibaye river catchment and on health policy and extreme events. These have been disseminated at the local, national and regional levels.

\section{Ecuador}

The institutional framework for forest and water management in general, and in relation to extreme events in particular, is quite chaotic and has been changing constantly over the last 20 years. Applicable legislation exists but it is not clearly understood by the different actors and therefore not generally applied in practice. However, the recent national review of the Ecuadorean Constitution provided an opportunity to influence policy by writing policy briefs specifically to communicate key messages to the working groups of the Constitutional Review. The four briefs cover the use of best scientific evidence for the development of policies relevant to extreme events, soil conservation and protection of native forests. These briefs were presented directly to policy makers in Quito. 


\section{Chile}

The presence of a big industrial forestry sector provided the opportunity to influence the practices of the main forestry companies. The project therefore concentrated on achieving agreements to incorporate improved management practices in the main certification systems operating in the country, involving companies and certifiers at an early stage of the process. It also sought to reach agreements with the forest public administration to incorporate improved practices as administrative rules in forest management plans. Success saw a range of proposals accepted for improvement of the forest plantation standard known as CERTFOR. A best management practice guide for minimizing soil erosion during forestry activities was also produced and will be considered as a working tool by the CERTFOR Forest Plantation Standard (Gayoso and Gayoso 2008). Policy briefs were produced on the issue of the impact of forest growth on water resources at local and catchment levels and the improvement of the certification standards mentioned above. These have been disseminated within the forest and water resources industries.

\section{Argentina}

The policy objectives were centred on the integrated management of water and forest resources for extreme events (including snowmelt) in Tierra del Fuego and other provinces of the Andean-Patagonian region. They included the generation of planning guidelines for forested catchments to be used by planning authorities at the municipal and provincial levels, which could be used throughout the Andean-Patagonian region, and the regulation of catchments specifically in Tierra del Fuego province. Interactions with policy-makers were very successful, resulting in the adoption by the Patagonian Water Resources Council COHIPA (Consejo Hídrico Patagónico) of recommendations for the management of Andean-Patagonian catchments in the drafts for the National Water Plan, and in recognition of the significance of the forest cover for the sustainable management of the Buena Esperanza catchment. Policy briefs were produced on reduction of catchment vulnerability in extreme events, planning of urban areas in torrent catchments and hydrological risk studies to support preventive planning. The briefs have been presented to the national and provincial water resources authorities.

\section{Conclusion}

The EPIC FORCE project aimed to combine an improved research base with historically derived best practice to develop evidence-based policy recommendations for integrated forest and water resources management, with specific relevance to extreme rainfall and snowmelt events. The general applicability of this approach was investigated in four Latin American countries. The results obtained from the combination of data analysis and model application support the hypothesis that, as the size of the flood peak increases, the effect of forest cover becomes less important. Figures 4 and 5, for example, support Figure 2. The convergence of response at high flows may be either absolute or relative. The results add to the previous literature by extending this finding to a range of Latin American forest and climatic environments and showing that the effect may be significant not only for small catchments (less than $10 \mathrm{~km}^{2}$ ) but for larger catchments (greater than $1,000 \mathrm{~km}^{2}$ ) as well, as long as the change in forest cover affects a significant proportion of the catchment. However, the pattern is complicated by a number of factors, which require further research. These include soil depth, antecedent moisture content and season, while in 
catchments with snowmelt regimes, forest cover can both increase and decrease peak discharges relative to the unforested case.

Building on firm hydrological understanding as well as successful past practice in water and forest management and restoration, a framework of guidelines was created within which strategies for integrated water and forest resources management could be developed. This combines mitigation of the impacts of floods with the management of water resources under all hydrological conditions, in support of a sustainable way of life for the inhabitants of the catchment. The guidelines recognize the limitations of afforestation as a technique for reducing the peak discharges of floods derived from extreme but infrequent rainfall events. For such events, forests are unlikely to protect lives and infrastructure from flooding and a more appropriate approach is zoning or land use planning. The guidelines emphasize, though, the effectiveness of forests in reducing the flood levels of more moderate events (which occur more frequently) and in reducing soil erosion and sediment loads at all levels of event. This role is central to the management strategies developed for the four focus areas. Forests also generate large woody debris in river channels. This debris has sufficient beneficial effects (such as slowing the flow, storing sediment and improving biodiversity) that its general removal is not recommended. A range of techniques is available for controlling its movement by high flows.

The forest impact research and the proposals for management strategies enable the basis for policy-making for water and forest resources management to be shifted from misperception to firm scientific evidence, while remaining strongly rooted in the best practice established through historical experience. A procedure for transferring the research findings to the policy-making arena has been established, with different approaches adopted to suit the different conditions of the four focus countries. Policy briefs have been produced at the local, national and international levels and project results have been put forward for national policies. Overall the EPIC FORCE project demonstrates how the integration of science, management and policy research can not only improve fundamental understanding of the underlying science but can also be applied systematically across a range of environments to recommend management and policy developments of real consequence for people and the environments in which they live.

\section{Acknowledgements}

Ian Calder, world-renowned forest hydrologist and colleague at Newcastle University, died in May 2009. This paper is dedicated to his memory, in acknowledgement of his substantial contribution to the initial ideas behind the EPIC FORCE project.

The EPIC FORCE project was led by Newcastle University (UK). The other partners were the Università degli Studi di Padova (Italy), the Universidad Politécnica de Madrid (Spain), the Universidad Nacional de Costa Rica, the Universidad de Cuenca (Ecuador), the Universidad Austral de Chile, the Universidad Nacional de La Plata (Argentina) and the Secretaría de Desarrollo Sustentable y Ambiente de Tierra del Fuego (Argentina). The project website is at http://www.ceg.ncl.ac.uk/ epicforce. The authors acknowledge the enormous amount of work carried out by their team members: A. Andreoli, H. Ayon, B. de Bièvre, S.J. Birkinshaw, P. Borja, C.I. Bovolo, S. Burns, I.R. Calder, P. Cisneros, C. Coello, F. Comiti, P. Crespo, J. Fallas, J. Gayoso, S. Gayoso, C. de Gonzalo Aranoa, V. Guerrero Borges, A. Huber, V. Iñiguez, R. Iturraspe, C. López Leiva, L. Mao, D. Mora, L. Opazo, M. Otoya, E. Pacheco, H. Palacios, F. Salas Pinel, J.C. Robredo Sánchez, J.P. Sánchez, R. Sarandón, A. Wijffels and J. Zaruma. The project was funded by the European Commission within the $6^{\text {th }}$ Framework Programme as part of its programme of Specific Measures in Support of International Cooperation under Contract Number INCO-CT2004-510739, and this support is gratefully acknowledged. The paper has benefited considerably from the comments of James Nickum and an anonymous reviewer. 


\section{References}

Andréassian, V., 2004. Waters and forests: from historical controversy to scientific debate. Journal of Hydrology, 291, 1-27.

Andreoli, A., Comiti, F., and Lenzi, M.A., 2007. Characteristics, distribution and geomorphic role of large woody debris in a mountain stream of the Chilean Andes. Earth Surface Processes \& Landforms, 32, 1675-1692.

Bathurst, J.C., Bovolo, C.I., and Cisneros, F., 2010. Modelling the effect of forest cover on shallow landslides at the river basin scale. Ecological Engineering, 36, 317-327.

Beschta, R.L., et al., 2000. Peakflow responses to forest practices in the western cascades of Oregon, USA. Journal of Hydrology, 233, 102-120.

Borja, P., et al., 2008. CD-ROM. Hydraulic characterization of Andean andosols and histosols. Geophysical Research Abstracts, 10 ( $5^{\text {th }}$ General Assembly of the European Geosciences Union), EGU2008-A-11539. (Abstract only)

Bradshaw, C.J.A., et al., 2007. Global evidence that deforestation amplifies flood risk and severity in the developing world. Global Change Biology, 13, 2379-2395.

Brath, A., Montanari, A., and Moretti, G., 2006. Assessing the effect on flood frequency of land use change via hydrological simulation (with uncertainty). Journal of Hydrology, 324, 141-153.

Buytaert, W., et al., 2005. The effect of land-use changes on the hydrological behaviour of Histic Andosols in south Ecuador. Hydrological Processes, 19, 3985-3997.

Calder, I.R., 2005. Blue revolution, integrated land and water resource management. 2nd ed. London: Earthscan.

Calder, I.R. and Aylward, B., 2006. Forest and floods: moving to an evidence based approach to watershed and integrated flood management. Water International, 31, 87-99.

CIFOR and FAO (Centre for International Forestry Research and Food and Agriculture Organization), 2005. Forest and floods: drowning in fiction or thriving on facts? [online]. Available from http://www.cgiar.org/insightdev/upload/291/145_BCIFOR0501.pdf [Accessed 2007]

Cisneros F., et al., 2007. Análisis de curvas de duración general para determinar el grado de degradación de cuencas hidrográficas. In: J. Feyen, L. Aguirre and M. Moraes, eds. Proceedings of the International Congress on Development, Environment and Natural Resources: Multi-level and Multi-scale Sustainability, 11-13 July 2007, Cochabamba, Bolivia. Cochabamba, Bolivia: Universidad Mayor de San Simon de Cochamba, D.L. 2-1*1269-07, 554-561. (In Spanish).

Coello., C., et al., 2007. Respuesta hidrológica de microcuencas con diferente cobertura vegetal. In: J. Feyen, L. Aguirre and M. Moraes, eds. Proceedings of the International Congress on Development, Environment and Natural Resources: Multi-level and Multi-scale Sustainability, 11-13 July 2007, Cochabamba, Bolivia. Cochabamba, Bolivia: Universidad Mayor de San Simon de Cochabamba, D.L. 2-1*1269-07, 516-523. (In Spanish).

Comiti, F., et al., 2008a. Wood storage in three mountain streams of the Southern Andes and its hydro-morphological effects. Earth Surface Processes \& Landforms, 33, 242-262.

Comiti, F., et al., 2008b. New methods for determining wood storage and mobility in large gravelbed rivers. Available from: http://www.ceg.ncl.ac.uk/epicforce/assets/D2Obis.pdf/

DeWalle, D.R., 2003. Forest hydrology revisited. Hydrological Processes, 17, 1255-1256.

Ewen, J., Parkin, G., and O'Connell, P.E., 2000. SHETRAN: distributed river basin flow and transport modeling system. Proceedings of the American Society of Civil Engineers, Journal of Hydrologic Engineering, 5, 250-258.

Gayoso Aguilar, J. and Gayoso Morelli, S., 2008. Guia de buenas prácticas para minimizar la generación de sedimentos por operaciones forestales. Valdivia: Universidad Austral de Chile. (In Spanish).

Harden, C.P., 2006. Human impacts on headwater fluvial systems in the northern and central Andes. Geomorphology, 79, 249-263.

Iroumé, A., et al., 2006. Respuesta de los caudales máximos al manejo de bosques de plantaciones en cuencas experimentales en el sur de Chile. In: Climate variability and change - hydrological impacts. Proceedings of the 5th FRIEND World Conference, La Havana, Cuba, 27 November-1 December 2006. Wallingford: International Association of Hydrological Sciences, Publication No. 308, 662-666. (In Spanish).

La Marche, J.L. and Lettenmaier, D.P., 2001. Effects of forest roads on flood flows in the Deschutes River, Washington. Earth Surface Processes \& Landforms, 26, 115-134.

López-Moreno, J.I., Beguería, S., and García-Ruiz, J.M., 2006. Trends in high flows in the central Spanish Pyrenees: response to climatic factors or to land-use change? Hydrological Sciences Journal, 51 (6), 1039-1050. 
Mao, L., et al., 2008a. Acumulaciones de detritos leñosos en un cauce de montaña de Tierra del Fuego: análisis de la movilidad y de los efectos hidromorfológicos. Bosque, 29, 197-211. (In Spanish).

Mao, L., et al., 2008b. Role and management of in-channel wood in relation to flood events in Southern Andes basins. In: D. de Wrachien, C.A. Brebbia and M.A. Lenzi, eds. Monitoring, simulation, prevention and remediation of dense and debris flow II. WIT Transactions on Engineering Sciences, Vol. 60.: WIT Press, 207-216.

Mintegui Aguirre, J.A. and Robredo Sánchez, J.C., 2008. Estrategias para el control de los fenómenos torrenciales y la ordenación sustentable de las aguas, suelos y bosques en cuencas de montaña. [Strategies for the control of torrent phenomena and the sustainable management of the water, soils and forests of mountain catchments]. Montevideo, Uruguay: UNESCO Documentos Técnicos de la PHI-LAC, no. 13. (In Spanish).

Warner, J., 2005. Multi-stakeholder platforms: integrating society in water resources management? Ambiente \& Sociedade, 8, 1-20. 